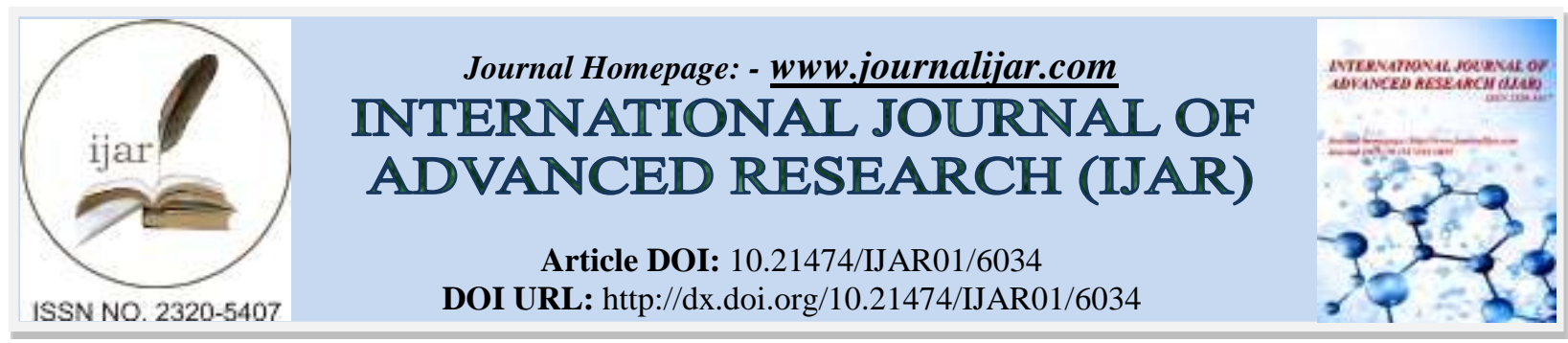

RESEARCH ARTICLE

\title{
IMPACT OF SCHOOL FACILITIES ON STUDENTS' ACADEMIC ACHIEVEMENT.
}

\section{Wunti Yakubu Ibrahim ${ }^{1}$, Hafsat Abdullahi Umar ${ }^{2}$ and Igbaji Clement ${ }^{3}$.}

1. $\mathrm{PhD}$ College of Education, Open, Distance and E-Learning Education Foundations, Kampala International University Uganda.

2. $\mathrm{PhD}$ Department of Education, Bayero University Kano Nigeria.

3. PhD Department of Education Foundations Sa'adatu Rimi College of Education, Kumbotso Kano Nigeria.

\section{Manuscript Info}

Manuscript History

Received: 12 October 2017

Final Accepted: 14 November 2017

Published: December 2017

\section{Abstract}

The paper examined the impact school facilities have on academic achievement of students in Senior Secondary Schools in Bauchi State Nigeria. The total population of the study comprises all the principals of Senior Secondary Schools in Bauchi State, numbering eighty-four (84), as of (2011). Employing simple random sampling technique, sixty-two principals were selected to represent the entire population as pointed out by Krejcie and Mogan, (1970). The instrument used for the study was Total Learning Environment Assessment (TLEA) consisting of 42 items completed by the principals, to ascertain the condition of the school facilities in public Senior Secondary Schools in Bauchi State. Data on result for students' academic achievement, (SSCE results) 2007-2011 were collected through the Bauchi State Ministry of Education. The TLEA instrument was adapted from the study of O'Neil (2000) redesigned by the researcher. A reliability tested through splithalf pilot study of calculated $=0.958$ and $r$ - critical value $=0.765$ at $\alpha$ 0.05 levels for Total Learning Environment Assessment for secondary school was sought to ascertain the usability of the instrument. Based on the analysis, the result shows that, the instrument has appreciable measures of validity and reliability. The data collected was analyzed using inferential statistics where the frequencies of the participants' responses were tabulated using percentages and Spearman Rank Order Correlation. Major research finding of the study did not find statistically significant relationship in the areas of school plant and facilities and students' academic achievement as measured by the TLEA at 0.05 levels. The researcher's recommendations based upon this study include the followings: Educational administrators, planners and other stake-holders should supplement the government effort by maintaining the school facilities and improvise these items locally from the immediate community where the schools are situated. An area of achievement and failure in the students' academic career needs to be evaluated in order to foster improvement and make full use of learning process.

Copy Right, IJAR, 2017,. All rights reserved. 


\section{Introduction:-}

The importance of school facilities in the development of effective educational system, particularly at the secondary school level cannot be over emphasized. The utilization of the goals and objectives of education require the provision, maximum utilization and appropriate management of the school facilities. This point is aptly stated in the

National Policy on Education that:

Education and training facilities shall continue to be expanded, to afford response to societal needs and made progressively accessible to the individual a far more diversified and flexible choice; (FRN 2004:13)

The design and size of school buildings have evolve over time. Many of the improvements reflected advancement in pedagogy and knowledge about environmental effects on learning. In the past, education was a much more informal activity than it is today and the physical setting for education was not considered important. Instruction usually occurred in open spaces or in structure designed for purpose other than teaching and learning. The early schools in Nigeria indicated that the national issues on education believed that the settings in which education occurred was of little consequence. This philosophy was visible in both school buildings and their locations, especially on the early schools. Very few architects (if any) were available to assist in the planning and construction of schools in the early days of education.

School can be viewed as an organized environment where educational curricular are interpreted. It is a formal structured organization which serves as a transitional stage in life between family and the society. School is a place where the child is prepared to function as an adult, and through this transformation by way of teaching and learning process, whose purpose is to bring about in the learner desirable positive and effective change in the behavior through critical thinking in a more conducive environment which is structured to facilitate learning.

The attainment of an effective and efficient teaching and learning is therefore dependent on teacher's quality, the location of the school, the organization and arrangement of physical structures and other school plant and facilities in the school. In the present day of technological advancement, there is need for the school principals to adopt modern method of plant and facility management which would improve the quality of teaching and learning. Nwagwu, (1978) and Ogunsaju, (1980) stressed the importance of school plant and facilities. They maintained that the qualities of education that children receive bear direct relevance to the availability or lack of physical facilities and overall atmosphere in which learning take place.

Secondary school, which according to FRN, (2004:13) "is the education children received after primary education and before the tertiary stage" needs school plant and facilities which consist of all types of buildings for academic and non-academic activities; equipment for academic and non-academic activities; areas for sports and games, landscape, farms and gardens, including trees, roads and paths. Other facilities needed by secondary schools include furniture and toilet facilities, lightings, acoustics, storage facilities and parking lots, security, transportations, cleaning materials, food services, and special facilities for special needs. Their appearance and maintenance influences most parents and convince them to make judgment about the qualities and effectiveness as to what goes on in the school. It is believed that, without such facilities, the empty buildings, no matter how attractive they are cannot be effectively used for educational purposes, (Ogunsajo, 1980)

Recently, the Nigerian secondary schools students' academic performance is generally poor going by the existing records, (Adesina, 2011); He posited that, there was persistent mass failure of students in senior secondary school examinations (SSCE) conducted by the West African Examinations Council (WAEC). Ajayi, (1997) asserted that, the observed poor academic performance of secondary students may not be unconnected with seemingly poor school plant planning in most Nigerian secondary schools. Mark, (2002 a) and Ajayi (1997) lamented that high level of students' academic performance may not be guaranteed where instructional space such as class rooms, libraries, technical workshops and laboratories are structurally defective. Enumerating the factors that could be responsible for intra and inter-school academic achievements, Jekayinfa, (2000) include acute scarcity of instructional resources which according to him attributed constrain of educational systems from responding more fully to new demands.

Mass failure in public examinations has relatively alarming proportions in the last few years. Ayorinde, (1986) opined that the outcome of our educational system has fallen below the minimal for our educational objectives and this according to him means that there is a failure in our curriculum, facility provision, our teachers and teaching method or our evaluation system. Educating all children at this time of economic meltdown presents a significant 
challenge due to the large number of children, especially in a developing country like Nigeria, where planning always posed a problem. There is need, therefore, to utilize and maintain the limited plant and facilities available in schools for quality teaching and learning effectiveness.

School plant and facilities that are deteriorated and inadequate may result in reduced learning time, alienated students, inability to provide specialized curriculum, low staff morale, lack of technology proficiency, safety hazards, high rates of teacher attrition, and a reduced ability to meet special needs (21st Century School Fund, 2002).

It is a common experience to see some schools today, where the environments are by far from being conducive for learning; where classroom spaces are inadequate, for most children are found to be compacted in classrooms, especially public institutions. In some cases learning take place under trees. Some schools are generally in a poor state of repair. Teachers' effectiveness and students' learning may be limited by inadequate learning materials. Poor working conditions and insufficient facilities have inevitably eroded motivation and satisfaction which demoralized teachers, education today must prepare the child for an all-round development (Corcoran, 1988)

\section{Significance of the Study:-}

The study will potentially have implications for policy-making, funding formulas and facility provision in Senior Secondary Schools in Nigeria.

The study has the potential of contributing to an existing knowledge in the field of educational planning, specifically; the result would provide room for the improvement of educational planning in Bauchi State and Nigeria in general. This is because the findings will assist in better understanding and improvement of school plant and facilities.

Understanding the adequacy, and impact that our current educational plant and facilities have on learning environments can guide facility renovations and the construction of new plant and facilities to be conducive to learning.

\section{Objectives of the Study:-}

The study sought to find out if there is relationship between school plant and facilities and students' academic achievement in Senior Secondary Schools in Bauchi State

\section{Research Question:-}

The study sought to answer the following question: Is there any relationship between school plant and facilities and students' academic achievement in public Senior Secondary Schools in Bauchi State of Nigeria?

\section{Hypotheses:-}

A null hypothesis was formulated for appropriate testing in the study; the hypothesis is intended to answer the research question.

\section{Ho1:-}

There is no statistically significant correlation between school plant and facilities and students' academic achievement in public Senior Secondary Schools in Bauchi State:

\section{Concepts of School Plant and Facilities:-}

School plant and facilities are the material resources provided for staff and students to optimize their productivity in teaching and learning process. The realization that the transfer of knowledge does not only take place in the four walls of the classroom from teacher to students but rather that, learning takes place through discovery, exploration, interaction with the internal and external environment has necessitated the creative and innovative development of teaching and learning facilities that reflect these changes (Asiabaka, 2008)

The concept of school plant and facilities according to Peretomode, (2005) are "those things of education" which enable a skillful teacher to achieve a level of instructional effectiveness that far exceeds what is possible when they are not provided. This definition failed to provide basis for distinguishing school and plant facilities from human resources. The 'things of education' is a wider scope, because 'things of education' is much more than school plant 
and facilities in educational circle, for it included the administrators, teachers, non-teaching staff and even the stakeholders of education who are not in any way school plant and facilities.

Wunti, (2014) defined school plant and facilities as "engines of growth in learning" which support the teacher and the learner for effective and efficient teaching and learning for the attainment of goals and objectives of education. Tahir, (2003) refers school plant and facilities "as physical and spatial enablers and enhancers of teaching and learning.

In the context of secondary school education, school plant and facilities includes classrooms, libraries, farms, gardens, laboratories, workshops, offices, stores, school buildings, staff quarters, chairs, tables, text books, magazines, journals, pictures, filmstrips, charts, bulletin board, posters, cartoons, school museums and archives chalk-board, play fields etc. Such physical structures that are available in Nigeria includes permanent structures, semi-permanent, temporary, mobile, collapsible, boat-school and even under the tree shade (Roy, 2008). He asserted that the goal of school plant and facilities development in primary education is to increase school attendance, motivation and to improve academic performance of students.

Asiabaka, (2008) observes that, school facilities constitute the major components of both direct and indirect elements in the environment of learning. According to him, the school plant and facilities are materials designed to serve specific purposes. She suggested the followings as the need for plant and facilities in schools, to provide opportunity for the firsthand experience, for experimentation and demonstration; for specific investigation, to provide diversity of thought; for observation and inquiry for development of scientific attitudes and skills, to protect the individual, provide comfort and to illustrate concepts;

Olakoya, (2004) contended that in an educational environment, such as secondary schools, it is indisputable that school plant and facilities such as furniture, laboratory equipment and materials have a great influence in the teaching and learning process because without them, the empty buildings and structures no matter how attractive cannot be used for educational purposes. Hence, school plant and facilities are no doubt an essential part of educational planning without which students' academic achievement cannot be enhanced.

The concept of functional plant of school buildings has grown and expanded with use. The term school plant means immoveable structure in the school. It include school building, playground, classroom hostel, library, apparatus and equipment, black-board, stores etc. While school facilities are moveable structures which are also designed to promote teaching and learning effectiveness.

Impact of School Plant and Facilities on Students' Academic Performance:-

Everything about a child that is changing rapidly in his early life suggest that the child's psycho-social and intellectual environment must be maximally stimulating to produce the best result for a child's intellectual development and smooth psycho-social adjustment to be realized. In line with the aforementioned, Suleiman, (2007) portends that as everything about the child is changing rapidly, also school plant and facilities in education must be changing rapidly too.

Like any other level of education, secondary education can be regarded as open system which receives inputs from the environment, convert or process them, afterwards discharges the inputs to the environment where the inputs were obtained. However, if the inputs are inadequate or poor, the conversion process would be defective, so also the outputs. On the other hand, if the inputs are available, relevant, adequate and judiciously utilized, it is certain that the outputs of the system will be at high standard. It can be stated at this juncture that just as the system output is proportional to its input available for processing, so also is true that a school's academic achievement is a function of the resources in different subject (Suleiman, 2007). Jekayinfa, (2000) lends support to Suleiman and sees education as having two components, "inputs and outputs" He lamented that, inputs consist of human and material resources and outputs are the outcomes of educational process. He asserted that both the inputs and the outputs form a dynamic organic whole and if one wants to investigate and assess the educational system in order to improve its performance, effects of one component on the other must be examined.

One potent index for evaluating educational standard and quality is an examination of the plant and facilities available for learning experiences. The overall emphasis of development plans in education, more often than not, addresses itself to quantitative issues. How many schools should be built and how many teachers are needed to teach 
the students within the projected period and from a limited specified sum of money? Yet the quality of education our students receive bear direct relevance to the availability or the lack thereof physical facilities and the overall atmosphere in which learning takes place. Besides, after determining the size of the student population to be served, it is essential to devote attention to the quality of school plant and facilities that would be provided for them (Adesina, 1990: 73)

Although availability of school plant and facilities alone is not sufficient condition for good performance; it is clear that schools which are better equipped with adequate provision of plant and facilities are more likely to produce a higher level of learning and motivation among the learners as compared to others. The primary purpose of provision of school plant and facilities equipment is to provide for the educational needs of students, however, school plant and facilities must relate to curriculum.

Adeogun, (2001) discovered that, a very positive relationship between instructional resources and students' academic performance exists. He asserted that, schools endowed with more resources performed better than schools that are less endowed. Collaborating this, Babayomi, (1999) asserted that, private schools, because of the availability and adequacy of teaching and learning resources performed better than public schools.

Dada, (1986) posited that, the quality and quantity of these materials (school plant and facilities) have been identified as significant factors determining students' performance. He further stated that the relevance and appropriateness of these learning resources to the local environment are important to the achievement of the national objectives and goals. Obanya, (2000) identifies school plant and facilities which promote education program as "didactic" materials. The key word didactic implies that, such materials should:

Meet the requirements of specific curriculum;

1. Use the learner as the basis of its content and orientation and

2. Help the learner to carry out specific activities geared towards meeting specific educational needs/curriculum requirements.

3. While the other key word "material" to imply some concreteness. While educational policies and curriculum guidelines may be stated in the abstract, and while methods may be perceived and not really seen, didactic material is a lot more tangible. Obanya, (2000), categorized didactic materials in to direct and indirect. Accordingly, didactic materials are in textual forms, such as books, diagrams, charts, laboratory equipment etc. which are consciously intended to facilitate the task of the teacher and learner.

Indirect didactic materials on the other hand are designed not primarily for facilitating formal learning and teaching and sometimes they are not even design at all. These include toy meant for play, machine and tools for work and natural sites for leisure, they could be used for didactic purposes.

The term reform and innovation need to be clearly defined to ensure that it is not anything new that is considered desirable for the national education system; innovations should be filtered to obtain what is desirable. Teachers should involve themselves on the development of school facilities and understand how to manipulate them for the benefits of students.

Adeogun, (2001) posited that, learning experience is richest when environment (physical resources) around them meets their needs through its adequacy and effective utilization. Adeogun, (2001) in his contribution asserted that, children learn well when they can actively explore an environment rich in adequate materials. Hinum, (1999) asserted that the quality of plant and facilities has an impact not only on educational outcomes but also on the wellbeing of students and teachers. In the same vein, issues related to school facilities such as instructional facilities, other researchers like Oladipo (2008) accepted the fact that, materials such as textbooks, magazines, journals, pictures, filmstrips, chalkboards, charts, bulletin board, posters, cartoons, school museums and archives go a long way in assisting teaching-learning process and invariably enhancing students' learning achievements.

On the other hand, Yinka, (2011) on his presentation, argue that the school plant and facilities themselves hinder rather than enhance good teaching practices. According to him, school plant and facilities in most Nigerian schools today are opt to reinforce rote teaching methods and further hinder the student capacity for independent and creative thinking. In contrary however, Victor, (2005) and Asiabaka, (2008) describe school plant as the major school facility in the school and viewed it as the space interpretation of the school curriculum. They emphasized that, the curriculum find its physical expression in construction and arrangement of the school plant, which is a controlled 
environment that facilitate teaching and learning process and also protect the physical wellbeing of the occupants. They further stated that since teaching and learning do not take place in a vacuum, school plant and facilities give meaning to the planned curricula. Asiabaka, (2008) emphasized that both teachers and students need places to read, confer, interact, listen, think, experiment, record and places to transact students' affairs or to gather for social purposes, this collaborate with Wunti, 2014, who opined that, school plant and facilities are engine of growth which support the teacher and the learner for efficiency and effective teaching and learning in the attainment of goals and objectives of education.

According to Enaohwo (1989), "the child is the focus of the school plant planning." The interest, especially the educational and physical well-being of the students are the major determinants of what the school plant should be. He further stated that students are in the school for learning in order to derive mental/intellectual, physical and social development, hence the school plant is incomplete without the necessary facilities for this development to take place. Corroborating these, Mark, (2002) and Ajayi, (2009) maintained that, high level of students' academic performance may not be guaranteed where instructional spaces such as classrooms, laboratories, libraries, technical workshops etc. are structurally defective.

The importance of school plant and facilities is therefore, very vital as one of the ingredient of student outcome. It is important for educational managers and stakeholders to ensure that the existing educational plant and facilities are regularly maintained so as to extend their useful life span for the benefit of teachers, students and even the community where the school is situated.

Open Spaces and Students' Academic Achievement:-

Open space is a land and or water area, with its surface open to sky, consciously acquired or regulated to serve conservation and shaping function in addition to providing recreational opportunities. Space can be utilized in a variety of ways. It can be provided for a freedom of movements, can be used for storage of teaching and learning materials. Students also use open space to keep their belongings (Wunti, 2004)

One of the many tasks of school plant is to determine the requirement of departments when requesting to relocate to space within the school premises or when the school considers renovating a building, construction of a new faculty or for a public usage. The school plant objectives are to provide the most economic viable and efficient space based on the department's program assessment and in conjunction with the school master plan and strategic initiatives. Space utilization is ongoing challenges, which involve creative adoptability without compromising the school functions. Open space in schools can be categorized into:

1. Corridors, lobby, staircases and other spaces where students recreate; and

2. Accessories which include parks, gardens, fields, courts and lawns.

The planning design and execution of school building should take into consideration the total space available to it. Most modern schools within the urban areas have limited space for accommodation hence, the reason for two, three story buildings within their compound. A school that is cited on an acre of land would have more space than another cited on two plots of land. While it is possible to ride within some schools, you hardly trek within some, the more spacious a school the healthier are the students and convenient for teachers and visitors of the school.

Mark, (2002 a); Ajayi (2009); Persuad and Turner (2008) pointed out that safe and orderly classroom environment (aspect of instructional space) school facilities (accessories) were related to students' academic performance in elementary schools. Open space is a useful school plant in the school environments. According to Enaohwo, (1989) "some of the open space are under developed, which is covered by vegetation and forest" such natural school plant where nature is brought closer to the learning environment are lacking in urban schools which are developed into agricultural land for the benefit of the school especially the students during demonstration lesson.

The planning and use of the conversion of existing spaces or the planning of a new space clearly relate to the amount support, advice, organizational constrains and direct control by the local authority as well as from the establishment in addition to constrain imposed by finance, safety regulation and legal requirements and architectural constrains. Others will be imposed by the existing users of spaces, linked both to historical use in relation to teaching/learning activities. Asiabaka, (2008) emphasized that more specific terms like expansible space that can allow for ordered growth, convertible space that can be economically adopted to program changes, versatile that serves many 
functional and malleable space that can be changed at once and at will should be used, this calls for team effort of both principal and other stakeholders for these to be achieved.

Asiabaka, (2008) postulated that, the physical needs of a child are met through provision of safe structure, adequate sanitary facilities, a balance visual environment, appropriate thermal environment and sufficient shelter space for his work and play. Students' emotional needs are met by creating pleasant surroundings, a free atmosphere and aspiring environment. Open space may contribute to students' academic performance, especially if the spaces are well utilized for effective teaching and learning. Therefore, care must be taken to preserve and manage open space in school, because the extent to which these spaces could enhance teaching and learning depends on how it is perceived and used. The value of open space in schools can be considered with regard to the specific functions it provides in achieving educational objectives which includes exposing the students to a natural environment and engaging them in physical education activities that enhanced performance in school.

\section{School Plant Planning and Specification:-}

The logical place to start school plant planning is the development of educational program. The school educational program should strongly influence the design of school plant. The basic principle here is no educational facility should impose unwanted restrictions upon the educational programmes. School plant planning expert agree that curriculum development is a crucial aspect of school plant planning. No architect can design a functional school building for a given educational need without a clear description of the educational program (Castaldi, 1977). Unfortunately, most of our school buildings erected indiscriminately set up by the private entrepreneur were just set up as buildings to house students without regard to proper planning in terms of what educational purpose the building should serve or their place in the delivery of educational program.

The school plant is considered as the entire scope of school buildings, laboratories, play field, school farms garden etc. are provided in the school for the purpose of educating the child. The school plant may be use directly and indirectly for educational purposes. "What matters for any school plant to be classified as an integral part of the school plant is that it must contribute something to the education of the child in the long run" (Enaohwo, 1989). Ijaduola, (2011) referred school plant as a process of management, construction, utilization and maintenance of school plant and facilities to ensure the achievement of educational goals and objectives.

The school educational programs, therefore, strongly influence the design of school buildings since no educational facilities should impose unwanted restrictions upon the educational programs. Thomas, Walker and Lynne, (1988) posited that, considerable time is always devoted to developing the curriculum of the school before actual planning or design of buildings begins. Jago, (1999) asserted that, the educational facilities planners take note of what subject would be taught, the basic educational concepts and student experiences. The designer should know what type of school plant is needed and how much space the teachers feel a student needs to perform each type of educational experience.

Kolawole, (2000) and Adepoju, (2001) studied school plant and facilities planning in relation to academic performance of secondary students in different areas. They use the factor of location of school plant planning and use the result of NECO and WAEC as the measure of academic performance. They found that school well planned and maintained had higher students' academic performance. Similarly, Babatunde, (2008) compared the academic performance of junior secondary school (JSS) and senior secondary school (SSS) students using the measures of school planning. The outcome of this study clearly indicated that students used in his case study performed well regardless of their academic level. It is clear evidence that the achievement of the overall goals and objectives of educational system revolves around the ability of learners to tap from various opportunities offered by the school and its environment. One of the opportunities offered by the school is therefore, the school plant. This perhaps is the reason why Ijaduola, (2011) professed that; the quality and quantity of the educational facilities available within an educational system have positive relationship with the standard and quality of the educational system.

It is therefore, important to realize that cost related to repair and replacement has escalated significantly and fuelled a new concern among facility planners and managers. It is therefore pertinent at this critical period of economic malt down to make case for school plant and facilities improvisation and effective maintenance and utilization of improvised instructional facilities in Nigeria. With the increase number of academic programs and limited resources, flexibility must be an integral part of the planning process. Facilities should be improvised such that it would meet the growing demand at all time. Asiabaka, (2008) argue that, more specific terms like expansible space that can 
allow for ordered growth, convertible space that can be economically adapted to program changes, versatile that serves many functional and malleable spaces that can be changed at once and at will, should be used.

Conversely, considering the studies made, school plant is the totality of all immoveable structure that make up a school system which include the physical and the material facilities in form of buildings, school site and the environment that embodied the school. Thus school plant planning is the positioning of school plant in a comfortable place where educational activities could be attained.

\section{Utilization of the School Plant and Facilities:-}

Whenever plant and facilities are made available in the school, it is important for such resources to effectively be utilized. If for instance, the utilization is below the norms or standard, the returns from such investment may become inadequate. Equally too, where the resources are over utilized, there is the tendency that resources may not be maximized. This may be common in our schools today; particularly secondary school where in an attempt to absorb primary school leavers, a classroom built to accommodate 40 students is constantly used for 80 or more students. Ovwigho, (2004) asserted that, as a result of over utilization and under-utilization of school plant facilities, which adversely affects school system, it is essential for planners and administrators to constantly analyze the rate of utilization of the premises in schools. Omaze, (2004) analyzed the efficiency of resource management and organization as the level of the frequency or number of times for which the resources are utilized appropriately for academic purposes in schools. He further stated that, the indicators of efficiency of school management and organization are the level of class size, periods of lessons per day and per week, school expenditure per student, frequency of school inspection, student-teacher and student-classroom ratio.

Nigeria as a developing nation strives to experience real growth and development, particularly in the present administration of Muhammadu Buhari. This requires clearly defined development strategies that allows for intensive utilization of the resources which are endowed. These resources are the various school plant and facilities that are indispensable in the educational process. They include buildings, physical equipment and recreational places for the achievements of educational goals and objectives (Adepoju, 2001 and Oluchukwu, 2000). Oluchukwu (2000) revealed that;

"school buildings and other facilities shall not only be functional servant of educational programmes, but shall also be friendly, attractive and stimulating to impact a feeling of security and a sense of pride to whom it served" They asserted that, school plant planning are essential aspect of educational planning and "unless schools are well suited, buildings adequately constructed and equipment utilized and maintained, much teaching and learning may not take place,

Researchers in Nigeria such as Balogun, (2000) and, Adeniran, (2006) identified the problems of adequacy of professionally sound and enduring committed school teachers with needed ingenuity to improve and utilize appropriate instructional facilities to enhance effective teaching and learning. It is therefore pertinent at this crucial time of financial crisis all over the world particularly developing country such as Nigeria where the economy is still in recession to make case for the effective utilization of school plant and facilities in secondary schools in order to avoid waste.

\section{Public Utilization of School Plant and Facilities:-}

The school principal with his heads of departments should decide whether school plant and facilities should be available for public use, if there is no government directive against it. An open-door policy which would require careful planning and cautious implementation or else the security of the school may be compromised and destruction through damages of school plant and facilities may be inevitable, particularly at this period of security challenges as a result of insurgency in the country.

Edem, (1998) opined that, the public can utilize the school plant and facilities in several ways, viz:

1. For conferences and exhibitions;

2. Opening the school library for the public;

3. Allowing the itinerant health officials to meet their clients in the school, especially in rural schools where there is no clinics or health facilities;

4. Clubs such as Boys scout, Boy's brigade, Girls guide, young Muslims and Christian societies can be extended to the local youth 
There are other usages which are not in the Edem list, such as allowing the school for adult literacy class, conducting professional examinations or holding symposia, workshops, and seminars by civil servants or even conducting elections to serve as a polling unit etc.

Whatever program is permitted by the public; the school plant and facilities in the school should be used after the school hours, so that normal school activities are not distracted. There should also be conditions for sharing the facility by the school to the public. Training programmes or skills upgrading programmes for which the school premises is used have to be recognized, accredited or certified by government or its agencies or other bodies of national or international repute. The physical facilities of the school may also be used for the conduct of vocation courses such as stenography, adult literacy, typing, computer training, creative arts, dramatics and sporting activities in collaboration with the people or organization proficient in the area concerned. When utilizing school plant and facilities, the user organization should be held responsible for any damage cause to such facility, (Ovwigho, 2004)

Since school is a community within the larger community, individuals and community groups shall be permitted to utilize the school plant and facilities for worthwhile purposes when such use does not interfere with the primary purpose of the school facility. The community should not schedule any event which may create a danger or risk, because of the inherent nature of the activity. Such activities like horse riding, fireworks, mechanical, rides, boxing, wrestling etc. may be avoided to protect students, staff and other employees of such school (Ovwigho, 2004)

\section{Data Analyses and Result:- \\ Research question:-}

Is there any relationship between school plant and facilities and students' academic achievement in Public Senior Secondary Schools in Bauchi State of Nigeria? To answer this question, a corresponding null hypothesis was formulated:

\section{Ho1:-}

There is no statistically significant correlation between school plant and facilities and students' academic performance in public Senior Secondary Schools in Bauchi State:

This hypothesis was tested using Spearman rank order correlation. To achieve this, samples of the public Senior Secondary Schools were ranked on Total Learning Environment Assessment (Academic Learning Space, Specialized Learning Space, Support Space, Community/Parent Space, and Environment for Education and Interior Environment) from the participants' responds (Principals N=62). Students' West African Examination Council (SSCE) results for 5 years (2007, 2008, 2009, 2010 and 2011) obtained from Bauchi State Ministry of Education, were also ranked which is used to rank order the students' academic performance. The paired rankings were correlated. The Correlation Matrix is presented in the table below.

Table 1:- Rank Order data analysis of the two variables, secondary schools Facilities and students' academic achievement

\begin{tabular}{|c|c|c|c|}
\hline \multicolumn{2}{|l|}{ Variables } & $\begin{array}{l}\text { Rank on school plant and } \\
\text { Facilities }\end{array}$ & $\begin{array}{l}\text { Ranking Academic } \\
\text { Performance }\end{array}$ \\
\hline \multirow{3}{*}{$\begin{array}{l}\text { Rank on school plant and } \\
\text { Facilities }\end{array}$} & Correlation Coefficient & 1.000 & .173 \\
\hline & Sig. (2-tailed) & . & .178 \\
\hline & $\mathrm{N}$ & 62 & 62 \\
\hline \multirow{3}{*}{$\begin{array}{l}\text { Ranking students' } \\
\text { Academic Performance }\end{array}$} & Correlation Coefficient & .173 & 1.000 \\
\hline & Sig. (2-tailed) & .178 &. \\
\hline & $\mathrm{N}$ & 62 & 62 \\
\hline
\end{tabular}

Rho. (Cal). $=0.173$

Table 1 presents the rank order of Senior Secondary Schools on school plant and facilities and students' academic achievement. The result of the analysis on the Table shows that the Rho $=0.173$. This indicates that, there is no significant relationship between school plant and facilities and students' academic achievement under study. However, it is observed that there is a positive relationship yet the correlation in this regard is low, not significant. Therefore the null hypothesis that, there is no statistically significant correlation between school plant and facilities and students' academic achievement in public Senior Secondary Schools in Bauchi State is accepted. 


\section{Finding:-}

At the end of the analysis, the finding was that, students' achievements were not found to be statistically significant in relation to school plants and facilities' conditions as measured by TLEA at the 0.05 level in senior secondary schools in Bauchi State.

\section{Discussion:-}

Interestingly, the result of this study yielded negative correlations between the TLEA sections and WAEC scores. This is in conflict with the majority of the literature on this topic. Many studies have shown that adequacy of school plant and facilities positively correlate with increase academic performance, for instance, Ayorinde, (1986) and Adeogun, (2001) asserted that, schools endowed with more resources performed better than schools that are less endowed.

One possible explanation for these results may be the diminutive size of the sample or from the lack of range between school WAEC scores. However, this study agree with Robert Scott McGowen, B.S. Texas A\&M University; M.S., University of Houston; Clear Lake High Schools, in his PhD dissertation, "The Impact of School Facilities on Student Achievement, Attendance, Behavior, Completion Rate and Teacher Turnover Rate at Selected Texas High Schools. (December 2007); where in his studies among others revealed that "student achievement, attendance and completion rate measures were not found to be statistically significant in relation to school plant and facility conditions as measured by the TLEA at the 0.05 level"

The result is also in collaboration with Hopland, (2013) studies, "School Facilities and Student Achievement in Industrial Countries: Evidence from the TIMSS Academic Journals Article" The paper studied the link between school plant and facilities (buildings and grounds) and student achievement in eight countries using data from the TIMSS 2003 database. The results indicated a negative relationship, but the estimated coefficients are mainly insignificant. Interestingly, the coefficients differ heavily across countries. Whereas there seem to be adverse consequences from poor facilities in Australia, the Netherlands and Japan, there is no significant effect in the remaining five countries, (Hopland 2013).

It remains an open question for future research why plant and facilities seem to play such a different role across countries, regions and states. The main lesson to be learnt from the present investigation is that school plant and facilities seem to have different impact across countries, regions and states

The result also relates to the report of Banjo Commission which reviewed the educational system in Western Nigeria in 1961, where he listed fifteen factors responsible for the falling standards of education, none of these fifteen factors reports form part of the 'poor provision of school plant and facilities' which could no longer be denied, particularly in Western Nigeria (Adesina, 1990).

The observed student achievement measures that were not found to be statistically significant in relation to school facility conditions in this study may be attributed to the students' poor study habits or higher absenteeism from the students, low initiative on the part of the teachers or leadership initiatives from the system. Where working conditions are good, it result in enthusiasm, high morale, cooperation and acceptance of responsibility.

\section{Recommendation:-}

The following recommendations are based upon the results of this study and will hopefully guide other investigations as data is gathered and analyzed on this very important topic.

-With this renewed emphasis on school outcomes such as academic achievement, and teacher turnover rates, government and other stake holders are searching for resources to improve public education. The construction, renovation and maintenance of school buildings represent a large percentage of annual school budgets. Both school administrators and planners must continue to search for facility characteristics that can most efficiently and effectively promote student achievement and educator professionalism. An area of achievement and failure in the students' academic career needs to be evaluated in order to foster improvement and make full use of learning process. 
-Result provides a framework for talking about how students fare in school, and a constant standard to which all students are held. Performance of result also allows students to be ranked and sorted a scale that is numerically obvious, minimizing complains by holding teachers and students accountable for the components of each grade. Performance of students can be done in a number of ways. For regular grading for example, students demonstrate their knowledge by taking written and oral tasks, performing presentations, turning in homework and participation in class activities and discussions.

- The government is certainly making an effort to provide necessary plant and facilities, but a lot more needs to be done. Bearing the importance of school plan and facilities to teaching and learning, government should as a matter of urgency make available adequate and effective school plan and facilities by increasing the allocation of facilities to schools; especially in areas where they are not adequate, so that teaching and learning could be made easier and the school management also needs to utilize these facilities provided to their benefit.

- Educational administrators, planners and other stake-holders should supplement the government effort by not only maintaining the school plant and facilities but also improvised these items locally from the immediate community where the schools are situated.

-Administrators and planners should take into account factors such as Interior Environment and Academic Learning Space when planning schools to positively impact student performance; school design and construction should focus on Specialized Learning Spaces and other academic areas more than administrative support spaces when striving to increase teacher satisfaction with physical working condition

\section{Conclusion:-}

This research work investigated the relationships among school plant facilities on students' academic achievement in public Senior Secondary Schools in Bauchi State of Nigeria. The observed low relationship between school plant and facilities and students' academic performance could be attributed to the students' poor study habits and low initiative on the part of the staff. Administrators and planners should take into account factors such as Interior Environment and Academic Learning Space when planning schools to positively impact student performance; school design and construction should focus on Specialized Learning Spaces and other academic areas more than administrative support spaces when striving to increase teacher satisfaction with physical working condition

\section{References:-}

1. Adeogun, A. A. (2001): The Principal and the Financial Management of Public Secondary Schools in Osun State: Journal of Educational System and Development. 5 (1) pp. 1-10

2. Adepoju, T. L. and Akinwunmi, F. S. (2001): Location of Secondary Schools as a Factor in Determining of Academic Performance of Students. Ibadan Journal of Education Studies 1 (20). 401-412

3. Adeniran, M. A. (2006): Strategies and Utilization of Improvised Instructional Materials and Students Achievements and Attitude in Ekiti State Secondary Schools, Nigeria: Journal of research in Education vol. 3, no. 2: The Development Universal Consortia; Ekere-Ekiti, Nigeria.

4. Adesina, S. (1990): Educational Management, Enugu; Fourth Dimension Pub. Ltd

5. Adesina, O. B. (2011): School Plant Planning as Correlated of Students' Academic Performance in South West Nigerian Secondary Schools. International Journal of Business Administration: Vol.2 No 2; Retrieved from www.sciedu.ca/ijba

6. Ajayi, K. (1997): Educational Leadership and the decision-Making process in a Depressed Economy in Olatunji, S. A. and Olagboye, A. A. (Eds) Managing Schools in a Depressed Economy; Lagos: Malhouse Press Limited

7. Asiabaka, I. P. (2008): The Need for Effective Facility Management in Schools in Nigeria: New York Science of Journal: Retrieved from http://www.sciencepub.org, SSN 154- 0200

8. Ayorinde, D. (1986): Mass Failure in Public Examinations (edited) (causes and problems); Proceedings of the National Conference on Mass Failure in Public Examinations $21^{\text {st }}-25^{\text {th }}$ April

9. Babatunde, A. J. (2008): Modern Strategies of School Plant Maintenance. African Journal of Studies in Education, 3 (2), 21-30

10. Balogun, E. M. (2000): Implementing Conceptual Change: A Strategy for Enriching Science Teaching in School. $40^{\text {th }}$ Annual Conference Proceedings of Science Teachers Association of Nigeria (STAN), 65-68.

11. Castaldi, B. (1997): Educational Facilities: Planning, Remodeling and Management, (Baston, Mass): Ellyn and Bacon

12. Corcoran et al (1988): Working in Urban Schools Washington D.C. Institute of Educational Leadership

13. Dada, A. (1986): Mass Failure in Public Examinations Causes and Problems: Proceedings of the National Conference on Mass Failure in Public Examinations, $21^{\text {st }}$ to $25^{\text {th }}$ April, 1986 
14. Enaohwo, J. O. (1989): Educational Administration. Ibadan: Paperback Publishers Limited.

15. Federal Republic of Nigeria (2004): National Policy on Education, Revised, Lagos N.E.R.D.C. Press.

16. Hopland, A. O. (2013): TIMSS Academic Journal Article: International Education Studies Vol. 6, No. 3

17. Ijaduola, K. O. et al, (2011): Empirical Analysis of School Plant Planning as a determinant Of Secondary School Students' Academic Performance .http://www.academicleadership.org/article/empirical-analysis-of-school-plantplanning-a------

18. Jago, E. and Tanner, K. (1999): Effects of the School Facility on Student Achievement-Visual (lighting and color): University of Georgia. http://www.coe.edu/sdpl//research abstracts/visual.htm

19. Jekayinfa, A. A. (2000): Effects of Instructional Resources on the Academic Performance Of students in History in Nigeria: Retrieved from http://www.unilorin.edu.ng/Publications/jekayinoluwa/2.o/o20effects o/c 200f o/o 20INST.......

20. Kolawole, E. B. (2000): Comparative Analysis of NECO and WAEC results in Mathematics and English Language in Ekiti State. Paper Presented at the Annual Meeting of the Nigeria Test and Measurement Association in Ife-Ode

21. Krejcie R.V. and Morgan D.W. (1970) Educational and psychological measurements - Determining sample size for research activity, U.S.A. Vol.30, pg $607-61$

22. Mark, S. (2002 a): Do School Facilities Affect Academic Outcomes? National Clearinghouse For Educational Facilities: National Institute of Building Science, 2002www.edfacilities.org

23. McGowen, R. S. (2007): The Impact of School Facilities on Student Achievement, Attendance, Behavior, Completion rate and Teacher Turnover rate in selected Texas High Schools (Unpublished PhD Dissertation): Texas: A\&M University

24. Obanya, P. (2000): Potentialities of Educational Materials in Africa in Inter-Learning of Education Innovation, Dakar: UNESCO, pp. 55-64.

25. Ogunsajo, S. (1980): Some Aspects of School Management: Ibadan.

26. Oladipo, S. A. and Adetoro, J. A. (2008): Geographical location and Institutional Facilities as a determinants of Academic Performance of Secondary School Students in Lagos State: Education for Millennium Development: Essays in Honour of Professor Michael Omolewa in 2 volumes: Vol.1; Ibadan; Spectrum Books Limied

27. Olakoya, O. K. (2004): Effective Instructional Materials in Teaching of Business Studies. Education Today 5 (1 and 2), 51-5

28. Oluchukwu, (2000): Challenges of Educational Planning in the $21^{\text {st }}$ Centaury; In Olagboye A. A., Fadipe, J. O. (Eds). Management of Nigerian Education: School Project Monitoring and School Plant Maintenance, NIEPA, Ondo.

29. Omaze, A. A. and Adewole, Gbenga J. (2004): Issues in Educational Measurement and Evaluation in Nigeria: In Honour of Wole Falayajo, Ibadan.

30. O'Neill, D. J. (1999): The impact of school facilities on student achievement, behavior, attendance, and teacher turnover rate at selected Texas middle schools in region XIII ESC: (Doctoral Dissertation, Texas A\&M University College Station)

31. Ovwigho, Y. M. (2004): The Theory and Practice of Educational Administration and Planning in Nigeria; Revised Edition, Benin City: Justice-Jeco Press and Publishers Limited

32. Peretomode, V. F. (2005): Introduction to Educational Administration and Supervisor; Educational Trust Fund Intervention (edited) Delta State University, Abraka: Joja Educational Research and Publishers Limited

33. Persuad, W. E. G. and Turner, T. (2008): In Linda, K. Lemasters (Ed): International Society for Educational Planning (ISEP) George, Washington, University Washington D. C.

34. Suleiman, Y. (2007): The Relationship between Human and Material Resources and Academic Performance, among Student of Adamawa Secondary Schools: Maiduguri Journal of Arts and Social Sciences (MAJASS) Vol.1 No.1

35. Victor, F. (2005): Introduction to Educational Administration, Planning and Supervision: Educational Trust Fund International 2004/2005: Jota Educational Research and Publishers Limited.

36. Wunti, Y. I. (2014): Impact of School Plant and Facilities on Students' Academic Achievement in Senior Secondary Schools in Bauchi State, Nigeria: Unpublished PhD. Thesis, Bayero University, Kano Nigeria.

37. Yinka, A. D. (2011): Modification of the School Physical Plant: A Catalyst for the Learning Experience: A Paper Presentation. 